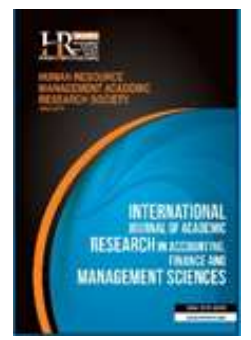

International Journal of Academic Research in Accounting, Finance and Management Sciences

Vol. 10, No.1, January 2020, pp. 165-171

E-ISSN: 2225-8329, P-ISSN: 2308-0337

(C) 2020 HRMARS

www.hrmars.com

To cite this article: Dias, M. O., Lopes, R.O.A. (2020). Case on Leading Commercial Aircraft in the Brazilian Domestic Aviation Market, International Journal of Academic Research in Accounting, Finance and Management Sciences 10 (1): $165-171$

\title{
Case on Leading Commercial Aircraft in the Brazilian Domestic Aviation \\ Market
}

\author{
Murillo de Oliveira Dias ${ }^{1}$, Raphael de Oliveira Albergarias Lopes ${ }^{2}$ \\ ${ }^{1}$ Coordinator of Executive Education Programs, Professor at Fundação Getulio Vargas, Brazil, \\ ${ }^{1}$ E-mail: agenda.murillo@gmail.com (Corresponding author) \\ ${ }^{2}$ Professor and Senior Lecturer at Fundação Getulio Vargas, Brazil
}

\begin{tabular}{|c|c|c|}
\hline Abstract & \multicolumn{2}{|c|}{$\begin{array}{l}\text { The Brazilian aviation market is the largest in Latin America, approximately \$10 billion in revenues in } 2018 . \\
\text { Thus, the global leading commercial aircraft manufacturers compete vigorously for a larger share of the } \\
\text { market. This article compared the performance of the leading airplanes in the domestic aviation market in } \\
\text { Brazil, operated by the three major Brazilian airlines, through descriptive case study and market analysis on } \\
\text { extensive archival research. Key findings pointed out the leaders within three categories: (i) more jumbo jets } \\
\text { Airbus A320, and Boeing 737-800; (ii) c-series jets Embraer ERJ 195, and (iii) turbofan ATR-72 600, among the } \\
N=499 \text { airplanes investigated within the three major airlines in Brazil, once the fourth competitor, Avianca } \\
\text { Brasil, was suspended of all flights and operations by ANAC in April 2019, as a precautionary measure } \\
\text { concerned with the safety of the operations, due to the company's filing bankruptcy. This work is useful to } \\
\text { civil aviation managers, agents, decision-makers, students, academics, and overall practitioners. Discussion } \\
\text { and future research compile the present article. }\end{array}$} \\
\hline Key words & \multicolumn{2}{|c|}{ Aviation Domestic Market, Aircraft Manufacturer, Brazil } \\
\hline Received: & 13 Mar 2020 & (C) The Authors 2020 \\
\hline Revised: & 15 Mar 2020 & Published by Human Resource Management Academic Research Society (www.hrmars.com) \\
\hline ublished Online: & 04 Apr 2020 & $\begin{array}{l}\text { This article is published under the Creative Commons Attribution (CC BY 4.0) license. Anyone may } \\
\text { reproduce, distribute, translate and create derivative works of this article (for both commercial and } \\
\text { non-commercial purposes), subject to full attribution to the original publication and authors. The full } \\
\text { terms of this license may be seen at: http://creativecommons.org/licences/by/4.0/legalcode }\end{array}$ \\
\hline
\end{tabular}

\section{Introduction and literature review}

This study investigated the Brazilian domestic aviation market, and compared leading aircraft operating in the country, as the unit of analysis (Yin, 1988). It aims to call into question the operation of the (i) larger jets ${ }^{1}$; (ii) c-series jets ${ }^{2}$, and (iii) the leading turbofans still operating in regional, short-haul flights, in the most significant Brazilian airlines, as well as their current performance.

The big four leading commercial aircraft manufacturers operating in Brazil are (i) the Brazilian EMBRAER; (ii) the North American Boeing; (iii) the French-Italian company Aviation de Transport Regional (ATR), and (iv) the European Airbus.

Moreover, the big four airlines in Brazil are: (i) GOL Linhas Aéreas; (ii) LATAM Airlines Group; (iii) Azul Linhas Aéreas Brasileiras SA, and (iv) Avianca Brasil, and respective market shares, as illustrated in the following Figure 1 :

\footnotetext{
${ }^{1}$ Jets over 100 seats

2 Jets up to 100 seats
} 


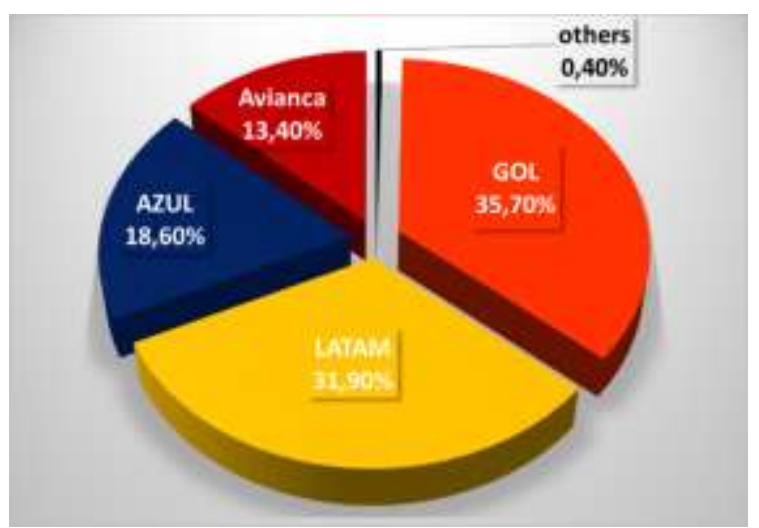

Figure 1. Principal Brazilian Airlines

Source: ANAC, 2020

Observe in Figure 1 that GOL is the leading aviation company (35.7 percent), followed by LATAM (31.9 percent), Azul, and Avianca. However, Avianca Brasil, officially Oceanair Linhas Aéreas, subsidiary of the Colombian Avianca Holdings, due to filing bankruptcy, had their flight operations suspended sine die by the National Civil Aviation Agency (ANAC) on May 24, 2019, as a precautious measure, primarily destined to secure with the passengers' safety (ANAC, 2020).Therefore, for 2020, the slice of Avianca's pie should be redistributed among the three major players in the Brazilian civil aviation market.

The results here investigated were achieved through qualitative, multiple-methods approach, such as descriptive case study combined with direct participation (once the authors are frequent fliers in all companies), and extensive archival research.

The primary motivation relies upon recent body of works in the civil aviation field of research: (i) air passenger transportation in Brazil (Dias, 2019); (ii) Brazilian airports [Congonhas Airport (Dias, 2020); Guarulhos International Airport (Dias, 2019); Brasilia International Airport (Dias, 2019b); Rio de Janeiro International Airport (Dias \& Albergarias, 2019, 2019b); Santos Dumont Airport (Dias, 2019c, 2019d)]; (ii) Civil aviation in Latin America (Dias \& Pessanha, 2019); (iii) Aircraft manufacturer industry (Cruz \& Dias, 2020; Dias et al., 2018; Dias and Duzert, 2018); (iv) air cargo transportation in Brazil (Dias \& Albergarias, 2020). In the next section, the research limitations and methods are presented.

\section{Methodology of research}

The present study combined qualitative, inductive reasoning and interpretive, multi-methods approach, such as single, descriptive case study (Yin, 1988), extensive archival research, and direct participation. The case unit of analysis is the Brazilian most significant commercial aircraft operating in the Brazilian civil aviation domestic market.

This case is limited to the Brazilian domestic aviation market, designed for regional flights. The international flight market, as well as respective manufacturers, regarding long-haul flights. In this article, we admitted long-haul flights as being more significant than $4,800 \mathrm{~km}$, and short-haul flights as being less than $1,100 \mathrm{~km}$.

This case is limited to the Brazilian domestic aviation market, designed for regional flights. The international flight market, as well as respective manufacturers, regarding long-haul flights ${ }^{3}$, is not considered here. Neither military aviation is not the scope of the present research, nor other modals of civil transportation.

Despite Avianca Brasil has been the fourth biggest airline in Brazil until May 2019, we opted for letting Avianca out of the scope of this research, because it not no longer operates in the Brazilian market, and the three major airlines have absorbed Avianca's share. This article is limited to passenger transportation. Cargo air freight transportation was not investigated here.

\footnotetext{
${ }^{3}$ In this article we admitted long-haul flights as being greater than 4,800 km, and short-haul flights as being less than 1,100 km.
} 
We investigated and compared the most significant airplanes operating in Brazil in regional, shorthaul flights, from the global aircraft manufacturers: (i) Airbus, A319, A320, A320 Neo, and A321; (ii) Boeing 737-700, and 737-800, once Boeing 737 MAX was grounded by the global aviation authorities due to failure project that culminated with two fatal air crashes (Cruz \& Dias, 2020); (iii) Embraer ERJ 190, and ERJ 195; (iv) ATR 72-600. Other aircraft are not part of this study.

Other airport activities are not investigated in this research, such as (i) parking lot administration; (ii) shopping centers; (iii) food courts; (iv) cargo operations, (v) car rental, (vi) shuttle transportation, among others.

Finally, this article is limited to the Ministry of Transport, Ports and Civil Aviation, represented by the National Civil Aviation Agency (ANAC), limited to Federal Law 11.182, from September 27, 2005 (Brasil 2005), and to the international Federal Aviation Administration's (FAA) and the International Air Transport Association's (IATA) international regulations (IATA, 2019). In the next section, the results of the Brazilian domestic air transportation market are presented.

\section{Domestic air market in Brazil}

Currently, near 93.6 million passengers were transported in $2018^{4}$ in 815,862 regional flights, according to the ANAC, as highlighted in the following Figure 2:

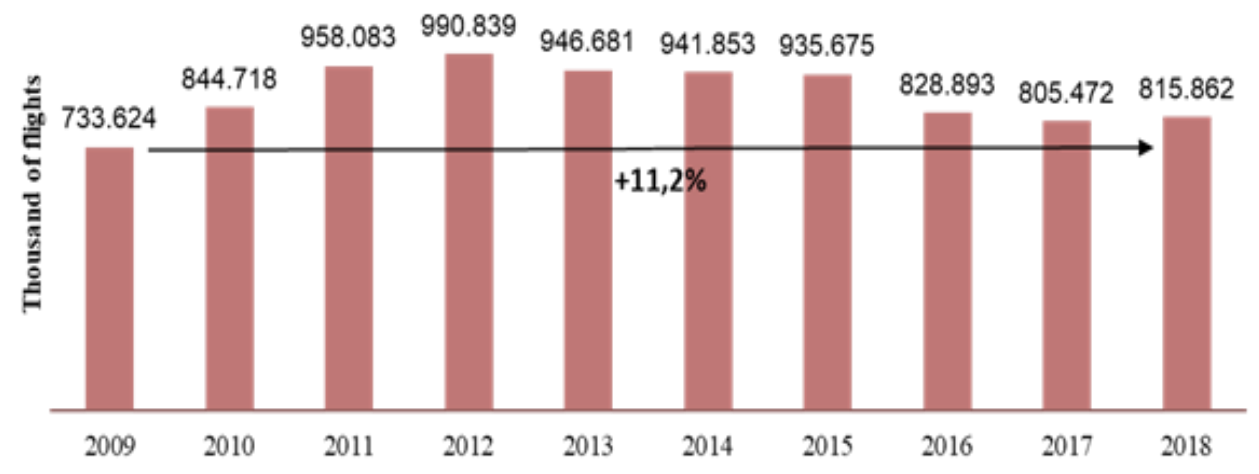

Figure 2. Flights in Brazil (2009-2018). Source: ANAC, 2020

Observe in Figure 2 the peak of passengers transported in 2012, and the downturn in subsequent years (2013 and 2018).

\subsection{Leading aircraft manufacturers operating domestic flights in Brazil}

To date, in total, 22219 aircraft are registered in the Brazilian Aeronautical Registry (RAB). Out of these, 640 are registered for air passenger transportation, including domestic and international flights ( 3 percent), from which 499 are investigated, as illustrated in Table 1, as follows:

Table 1. Brazilian aircraft per manufacturer (2014-2018)

\begin{tabular}{|l|r|r|r|r|r|}
\hline Manufacturer & $\mathbf{2 0 1 4}$ & $\mathbf{2 0 1 5}$ & $\mathbf{2 0 1 6}$ & $\mathbf{2 0 1 7}$ & $\mathbf{2 0 1 8}$ \\
\hline Airbus & 183 & 195 & 195 & 189 & 193 \\
\hline ATR & 76 & 78 & 56 & 54 & 47 \\
\hline Boeing & 184 & 186 & 171 & 166 & 186 \\
\hline EMBRAER & 89 & 91 & 76 & 74 & 63 \\
\hline Fokker & 11 & 7 & - & - & - \\
\hline Total & $\mathbf{5 4 9}$ & $\mathbf{5 6 1}$ & $\mathbf{4 9 8}$ & $\mathbf{4 8 3}$ & $\mathbf{4 9 9}$ \\
\hline
\end{tabular}

Source: ANAC, 2020

\footnotetext{
${ }^{4}$ Last official ANAC's data available, from September 2019 (see ANAC, 2020).
} 
Observe in Table 1 that Airbus, Boeing, Embraer (the only Brazilian aircraft manufacturer and global leader of jets up to 100 seats), and ATR are the leading airplane manufacturers operating in Brazil, according to the ANAC (2020). The Dutch Fokker, however, does not operate in Brazil since 1996, due to bankruptcy. The last seven Fokkers were terminated in 2015. Note that Airbus is the leading aircraft manufacturer operating in Brazil, with 193 airplanes, mostly 737-800s.

\subsection{Leading airplanes operating domestic flights in Brazil, per airline}

Observe in Table 2, the three leading airlines in Brazil and their respective airplanes:

Table 2. Brazilian airlines and respective airplanes

\begin{tabular}{|c|c|c|}
\hline Airline & Aircraft & Qty \\
\hline \multirow{5}{*}{ GOL } & Boeing $737-700$ & 24 \\
\hline & Boeing $737-800$ & 91 \\
\hline & Boeing 737 MAX 8 & 7 \\
\hline & Boeing 737 MAX 10 & - \\
\hline & Total & 135 \\
\hline \multirow{5}{*}{ LATAM } & Airbus A319-100 & 46 \\
\hline & Airbus A320N & 13 \\
\hline & Airbus A320-200 & 136 \\
\hline & Airbus A321-200 & 49 \\
\hline & Total & 244 \\
\hline \multirow{12}{*}{ AZUL } & Boeing & \\
\hline & 737-400F & 2 \\
\hline & Airbus & \\
\hline & A321 Neo & 12 \\
\hline & A320neo & 39 \\
\hline & ATR & \\
\hline & $72-600$ & 33 \\
\hline & Embraer & \\
\hline & 190 & 6 \\
\hline & 195 & 47 \\
\hline & $195 \mathrm{E} 2$ & 5 \\
\hline & Total & 144 \\
\hline
\end{tabular}

Source: ANAC, 2020

Note in Table 2 that GOL operates in the domestic market with Boeing 737s, especially the 737-800, with 91 airplanes. Observe that LATAM, on the other hand, operates exclusively with Airbus, currently 136 Airbus A320-200. Azul operates with both Embraer ERJ 195, with 47 aircraft (the only Brazilian airline operating with airplanes made in Brazil), ATR 72-600 (33 units acquired from Trip Linhas Aéreas), and 39 Airbus A320 Neo. In the next section, we compare most of the airplanes aforementioned, leaders in each airline.

\subsection{Comparison between leading airplanes operating domestic flights in Brazil}

In this section, we present a comparison between the following aircraft: (i) Boeing 737-700 and 800; (ii) Airbus A320-200, and A321-200; (iii) Embraer ERJ 190 and 195; (iv) ATR 72-600, as detailed in the following Table 3.

Observe in Table 3 the differences between the most frequently used aircraft in the Brazilian domestic market. Out of these airplanes, ATR 72-600 is the shortest airplane, suitable for short flights, with proportional capacity for passenger transportation (70 seats). On the other hand, Airbus A321-200 is the longest aircraft investigated (44,51 m length), also the highest flight autonomy, and the most expensive of the group ( $\$ 116$ million each). In the next section, analysis and case discussion is presented. 
Table 3. Comparison between Airbus, Boeing, ATR and Embraer's leading aircraft operating in Brazil

\begin{tabular}{|c|l|c|c|c|c|c|c|c|c|c|}
\hline \multirow{2}{*}{ Manufacturer } & Aircraft & $\begin{array}{c}\text { Capacity } \\
(\text { passengers })\end{array}$ & $\begin{array}{c}\text { Max Flight } \\
\text { Autonomy } \\
(\mathbf{k m})\end{array}$ & $\begin{array}{c}\text { Lenght } \\
(\mathbf{m})\end{array}$ & $\begin{array}{c}\text { Wingspan } \\
(\mathbf{m})\end{array}$ & $\begin{array}{c}\text { MTOW } \\
(\mathbf{x} \text { 1000 } \\
\mathbf{K g})\end{array}$ & $\begin{array}{c}\text { Cost } \\
(\mathbf{m i l l i o n} \\
\text { USD })\end{array}$ & $\begin{array}{c}\text { Max Vel } \\
(\mathbf{k m} / \mathbf{h})\end{array}$ & $\begin{array}{c}\text { Max Alt } \\
(\mathbf{m})\end{array}$ & Motor \\
\hline \multirow{2}{*}{ Boeing } & Boeing 737-700 & 138 & 5648 & 31.2 & 34,3 & 66 & 89.1 & 870 & 11.890 & turbofan bimotor \\
\cline { 2 - 12 } & Boeing 737-800 & $177-186$ & 5665 & 39.5 & 34,3 & 79,01 & 106.1 & 870 & 11.890 & turbofan bimotor \\
\hline \multirow{2}{*}{ Airbus } & Airbus A320-200 & $132-220$ & 5.700 & 37.57 & 34.10 & 42.4 & 99 & 871 & 11.890 & turbofan bimotor \\
\cline { 2 - 12 } & Airbus A321-200 & 196 & 5.600 & 44.51 & 34.10 & 48.2 & 116 & 871 & 11.890 & turbofan bimotor \\
\hline \multirow{2}{*}{$\boldsymbol{A T R}$} & $72-600$ & 70 & 1.500 & 27,17 & 27,05 & 22,8 & 25 & 511 & 7.620 & twin engine turboprop \\
\hline \multirow{2}{*}{ Embraer } & 190 & 106 & 4.448 & 36,24 & 28,72 & 51,8 & 46,2 & 829 & 12500 & turbofan bimotor \\
\cline { 2 - 11 } & 195 & 118 & 4.077 & 38,65 & 28,72 & 52,2 & 47 & 871 & 12500 & turbofan bimotor \\
\hline
\end{tabular}

Sources: Boeing (2020); Airbus (2020); ATR (2020); Embraer (2020)

\section{Discussions and Conclusions}

The Brazilian Air Market presented, in 2018, a slight recovery from the downturn since 2012. In 2018, 967 thousand scheduled and non-scheduled flights were carried out, from these, 815 domestic flights. The number of passengers transported reached 93.6 million domestic passengers. The total revenues in the period were $\$ 10$ billion, approximately, the largest air transport market in Latin America.

Nevertheless, the global manufacturers evidenced optimism due to the increasing number of orders, with one exception: Boeing 737-MAX 8 orders were canceled after two flights crashed late 2018 and since Boeing the end of the Boeing 737-MAX series (four in total) production. In Brazil, GOL was the only airline affected, once had acquired seven 737 MAX-8, currently grounded at Minas Gerais, Confins Airport (Cruz \& Dias, 2020).

Embraer, for instance, who traditionally manufactured airplanes up to 100 seats, launched the second generation of jets, E2 (E175-E2, E190-E2, and E195-E2), more substantial, faster planes to compete against Airbus A200 series. The Embraer jet E2 195, for instance (might in the future substitute current E195), has a passenger capacity of 144 seats, against the current 118 seats, $41.5 \mathrm{~m}$ long (against the current $38.5 \mathrm{~m}$ ), reaching 4,600 km (against current 4,077 km), with a cost of $\$ 65.6$ million, quite less expensive than Airbus A320, which costs $\$ 99$ million (Table 3).

After the ups and downs in the Boeing's failed acquisition attempt on Embraer (Dias \& Teles, 2018, 2019), both announced a joint venture to design, build, and sell commercial aircraft in the global market. The joint venture was established in February 2019, and the new company is called Boeing Brazil (80 percent Boeing's, and 20 percent of Embraer's shares). The partnership may implicate for the next ten years increasing participation in the domestic air flight market, further heating up the fierce competition between the largest aircraft manufacturers in the world.

Finally, this article condensed sparse data in a single, unpublished work. This study might implicate and be useful in other fields of research, such as (i) budgetary control (Al kaabi et al., 2020); (ii) international airport administration (Dias et al., 2020), (iii) other transportation modals, such as rail transportation (Dias \& Albergarias, 2019), among others.

\section{Recommendations}

Future research is encouraged on the impact of the joint venture Boeing-Embraer (Boeing Brazil) in the air transportation market in Brazil for the next decade. Also encouraged is the research on the impact of the Corona-virus pandemic (COVID-19), which implicates in airports closed, flights canceled all over the world, entirely unknown, and barely estimated, this far. It might provoke a significant downturn in the global aircraft manufacturers' revenues, once the whole sector is affected. Studies are also encouraged on the new jet family Embraer E2 on the civil aviation market in the next few years. 


\section{References}

1. Al kaabi, O. M. S. M., Adaikalam, J., Karim, M. A. M. (2020). A Case Study on Budgetary Control Application in the Ministry of Interior, UAE, International Journal of Academic Research in Accounting, Finance and Management Sciences 10 (1): 1-12

2. Yin, R. (1988). Case Study Research: Design and Methods. Newbury Park, CA: Sage

3. ANAC. (2020). Dados e Estatísticas. Retrieved from https://www.anac.gov.br/assuntos/dados-eestatisticas, on February 16, 2020.

4. Airbus. (2020). Commercial Aircraft. Retrieved from https://www.airbus.com/aircraft.html, on March 13, 2020.

5. ATR. (2020). Products. Retrieved from http://www.atraircraft.com/products/list.html, on March $13,2020$.

6. Boeing. (2020). Commercial Aircraft. Retrieved from https://www.boeing.com/commercial/, on March 13, 2020.

7. Embraer. (2020). Commercial Aviation. Retrieved from https://embraer.com/global/en/ commercial-aviation, on March 13, 2020.

8. IATA. (2020). Annual Review 2019. Retrieved from https://www.iata.org/contentassets/c81222d 96c9a4e0bb4ff6ced0126f0bb/iata-annual-review-2019.pdf, on February 15, 2020.

9. IATA. (2019). Standards. Retrieved from https://www.iata.org/pages/airports.aspx, on October 8, 2019.

10. Dias, M., de Oliveira, Lopes, R., Teles, A. (2020). Air Passenger Transportation: Hartsfield-Jackson Atlanta International Airport. In: Journal of Xidian University. Vol. 14 (3), pp.78-84. ISSN:1001-2400 DOI: 10.13140/RG.2.2.32181.42726

11. Dias, M. O. (2020). Air Cargo Transportation in Brazil. In: Global Scientific Journals. Vol 8, Issue 2, pp. 4180-4190, February/2020. ISSN: 2320-9186. DOI:10.13140/RG.2.2.30820.32648Dias, M.O. (2019). Air Passenger Transportation in Brazil. In: Global Scientific Journals. Vol 7, Issue 10, pp. 310-317, October/2019, DOI: 10.13140/RG.2.2.26800.71688.

12. Dias, M. O. (2020). Air Transportation in Brazil: São Paulo Congonhas Airport. In: Global Scientific Journals. Vol 8, Issue 2, pp. 3244-3252, February/2020. ISSN: 2320-9186. DOI: 10.11216/gsj.2020.02.35259

13. Dias, M. O. (2019). Air transportation in Brazil: Guarulhos International Airport. In: South Asian Research Journal of Business and Management. Vol. 1 (4), December/2019, pp. 182-187. ISSN 2664-6757 (Online). DOI: 10.36346/sarjbm. 2019.v01i04.00

14. Dias, M., de Oliveira, Albergarias, R. (2019). Rail Transportation in Brazil: Challenges and Opportunities. In: Arabian Journal of Business and Management Review (Kuwait Chapter), Vol. 8 (4), December/2019, pp. 40-49. ISSN: 2617-3018. DOI: 10.13140/RG.2.2.27687.70568

15. Dias, M. O. (2019). Brasilia International Airport and the Evolution of Civil Aviation in Brazil. In: East African Scholars Journal of Economics, Business and Management, ISSN 2617-7269 (Online). Volume-2, Issue-12, Dec-2019, pp. 734-737. DOI: 10.36349/EASJEBM.2019.v02i12.038

16. Dias, M. O., Albergarias, R. (2019). The Evolution of Civil Aviation in Brazil: Rio De Janeiro International Airport Galeão/Tom Jobim. JResLit Journal of Science and technology, 2019; vol1-issue 2, pp. 1-6. DOI: 10.13140/RG.2.2.15920.10242

17. Dias, M. O. (2019d). Santos Dumont Airport: Civil Aviation in Rio de Janeiro, Brazil. In: Saudi Journal of Engineering and Technology, Vol.4, Issue 10, pp. 418-421 October/2019, ISSN 2415-6264. DOI: 10.36348/SJEAT. 2019.v04i10.00

18. Dias, M. O., Pessanha, M. T. (2019). Air Passenger Transportation in Latin America. In: Global Scientific Journals. Vol 7, Issue 1, pp. 144-156, November/2019, ISSN: 2320-9186. DOI: 10.11216/gsj. 2019.11.30373

19. Dias, M. O., Albergarias, R. (2020). Air Cargo Transportation in Brazil. In: Global Scientific Journals. Vol 8, Issue 2, pp. 4180-4190, February/2020. ISSN: 2320-9186. DOI:10.13140/RG.2.2. 30820.32648

20. Cruz, B. S., Dias, M. O. (2020). Crashed Boeing 737-Max: Fatalities or Malpractice? In: Global Scientific Journals. Vol 8 , Issue 1, pp. 2615-2624, January/2020. ISSN: 2320-9186. DOI: 10.11216/gsj.2020.01.3491 
21. Dias, De Oliveira, M., Lopes, R., Teles, A. (2020). Air Passenger Transportation: Hartsfield-Jackson Atlanta International Airport. In: Journal of Xidian University. Vol. 14, Issue 3, pp.78-84. DOI: 10.13140/RG.2.2.32181.42726

22. Infraero. (2019). Estatísticas. Retrieved from http://www4.infraero.gov.br/imprensa/noticias/ santos-dumont-volta-a-receber-voos-neste-sabado-21-9, on October 8, 2019.

23. Brasil. (2005). Lei no 11.182, de 27 de setembro de 2005. Cria a Agência Nacional de Aviação Civil -ANAC, e dá outras providências. Retrieved from http://www.planalto.gov.br/ccivil_03/_ato20042006/2005/Lei/L11182.htm, on March 10, 2020.

24. GOL. (2020). Nossa Frota. Retrieved from https://www.voegol.com.br/pt/a-gol/nossa-frota, on March 10, 2020.

25. LATAM. (2020). Nossa Frota. Retrieved from https://www.latam.com/pt_br/conheca-nos/sobrenos/nossa-frota/, on March 10, 2020.

26. Azul. (2020). Azul em números. Retrieved from https://www.voeazul.com.br/imprensa/ informacoes-corporativas, on March 10, 2020. 